\title{
The Embodiment of Cross-cultural Content in the College English Teaching Textbook
}

\author{
Liu Xiaoyi \\ Foreign Language Department \\ Jilin Business and Technology College \\ Changchun, China \\ 182076127@qq.com
}

\begin{abstract}
Under the background of globalization, the international exchanges and cooperation are increasingly frequent, and the collision, exchange and fusion of different cultures are an inevitable reality. Cross-cultural ability has become a necessary quality for the modern talents. The trend has provided a new goal and research direction for theory research and teaching practice of English teaching in China. Colleges in our country is the base of all kinds of talent training, where English education needs to adapt to the development and needs of times and focus on the cross-cultural communication competence of college students. There is a close relationship between English teaching textbook and English education, which has profound influence on various aspects of teaching and learning. "New horizon college English textbook", as a widely used college English teaching material throughout the country, is worth an in-depth analysis and investigation on its emphasis on cross-cultural communication competence. Based on the perspective of the cultivation of cross-cultural competence, this paper aims to explore the effect of China's college English teaching material content on college students' cross-cultural communication competence aiming to have new discoveries on college English teaching in our country.
\end{abstract}

Keywords-College English; Western culture; English teaching materials

With the advent of the information age and the economic globalization, more and more international cooperation and communication are promoted and multicultural "global village" is formed. The rapid development of information and economy in the process of globalization has to some extent accelerated the cross-cultural communication among countries around the world. As a globalized language, English is universally acknowledged as an international tool of communication, in view of which, students must be well cultivated to have a good command of English and develop their cross-cultural communication competence. Since language and culture are closely related to each other, the necessity of integrating culture teaching in foreign language education has been long recognized by scholars and educators. They all agreed that the purpose of foreign language teaching is to help learners to understand communicative and cultural context where the language is used. In 2011, Ministry of education of China promulgated the new English Curriculum Standard for Compulsory Education, it points out that developing students' intercultural awareness and intercultural communicative competence is an important target of English teaching. Besides,
English textbook is a main channel for teachers to conduct culture teaching.

\section{Culture AND LANGUAGE LEARNING}

\section{A. Definition to culture}

Culture, as a most complicated and comprehensive term, has already been given more than 250 definitions by the end of 1996 (Nan, 2005). Since then, many additional definitions have also been offered and different scholars have different definitions to culture from different perspectives.

Tylor, the first scholar who gave a complete and clear definition to culture, referred to culture as "the complex whole which includes knowledge, beliefs, arts, morals, laws, customs, and other capacities and habits acquired by men as members of society" (Hutchins, 1995: 353)in his Primitive Culture, in which he also emphasized the relation between culture and knowledge, convention, ability and habit, etc.

Further on, culture was recognized as a combination of knowledge, experience, beliefs, values, attitudes, meanings, social hierarchies, religion, notions of time, roles, spatial relationships, concepts of the universe, and material objects and possessions by Samover and Porter (2007)[1]. All the above elements are acquired by people in the course of generation. The definition to culture proposed by Samover and Porter (2007) embodies the associated content to culture in all views and from all perspectives, covering almost all the visible and invisible concepts.

\section{B. The relationship between culture and language}

It is of great necessity to firstly clarify the relationship between language and culture become they are closely related to each other in many aspects, which have previously discussed by scholars and linguists from various perspectives. Therefore, on basis of the relevant researches, this paper concludes the points of view on the relationship between language and culture in the following. To begin with, it is no denying the fact that language and culture cannot be separated from each other in spite of the fact that they are two independent concepts. As was stated by Sapir (1921:99), "language is not isolated from culture." , which obviously points out the relation between language and culture. Scholar Kluckhohn (1944:26) also proposed that "Human culture without language will be 
inconceivable.” Similarly, Rivers (1981: 315) shared the viewpoint that "language cannot be separated completely from the culture in which it is deeply embedded." To follow with, as a dispensable part of culture, language can be understood as a certain set of norms spoken by people in a particular group or community. The integral relationship between language and culture is elaborated as "Language plays a vital role in the formation of culture.” by Deng Yanchang and Liu Runqing (1989: 3). Another scholar Shen Xiaolong (2000) held the similar opinion as "Language is a vital part of culture, which can serve as a subsystem in the integrity of culture.” To end with, language can have an inevitable influence on culture not only in the process of cultural spreading as a communicative tool but also in the development of culture. For one thing, as the well-known Sapir-Whorf hypothesis puts "the manner in which a person is thinking or behaving in is greatly affected by the structural system of the language he speaks in habitual communication.” (Kramsch, 2000: 11) In other words, people’s way of expression varies from the language used by people in a particular context. For another, language and culture can mutually promote each other in the process of formation and development, as Xing (2000:1) presented, culture is to some degree determined or limited by language in a particular way. Therefore, we can concluded language and culture as two mutually restricted concepts which are tightly attached to each other, which is the reason why language teaching cannot get separated from cultural education. Cultural awareness is accordingly quite influential and prominent in English teaching of middle school.[2]

\section{Cross-Cultural Content Analysis in New Horizon COLLEGE ENGLISH}

\section{A. Brief introduction to New Horizon College English}

Under the guidance of "college English curriculum requirements”, college English teaching material is gradually mature after repeated change and modification. New Horizon College English (the second edition) was published by foreign language education and research center in Beijing, which is suitable for teaching materials of the foreign language education in domestic universities and the most widely used material in the foreign language education in university. Therefore, New Horizon College English has certain representativeness in the following aspects: 1. New Horizon College English fully implements the spirit of the course requirements and attaches great importance to the important role of the modern information technology in training students' English comprehensive ability. 2. New Horizon College English reflects a scientific and rational view of language learning and curriculum view in its design and preparation, changing the traditional teaching concept and guiding ideology. Especially in the aspect of cultivating students' English comprehensive ability, the new teaching material design has made a breakthrough progress, putting emphasis on cultivating students' cross-cultural competence and the ability to use language, no longer limited students to language knowledge learning. 3. From the perspective of curriculum development, New Horizon College English lays emphasis on students' stepping from language knowledge learning to act as the principal part of learning.

\section{B. Analysis of intercultural content in textbook based on Buttjes and Byram's theory}

A constant stream of scholars and linguists have conducted researches on intercultural communication with the deepening of culture-oriented teaching of foreign language in schools, such as Brooks, Nostrand and Robinson and so on, aiming to find out a mode of high feasibility for students to better understand language and its culture and then improve their intercultural communication competence through learning language (Chen, 1999). It happens that there is a similar flourishing case in China, as a great many domestic scholars are undertaking researches on the theme of intercultural communication in recent decades. Scholars like Hu Wen zhong \& Gao Yihong (1997), Chen Shen (1999) and Gu Jiazu(2000) all have discussed this theme from their perspectives. Representatively, Zhang Weidong \&Yangli (2012) made a systematic study on foreign language teaching and intercultural communication, which offers a comprehensive and complete theoretical framework for the foreign language education and intercultural communication competence cultivation in China and can be divided into three dimensions: cultural awareness, cultural knowledge and communicative practice. More comprehensively, English scholar Byram (1997) also carried out a research on international communication competence and explained that international communication competence is reflected as the following four dimensions: knowledge, skills, attitude and awareness. In the further co-work of Byram and Buttjes (1990)[3], international communication competence was interpreted more concretely and evaluation of foreign language material was done by the following standards: microscopic cultural level (characters' everyday life and activity in the textbooks), macroscopic cultural level (political, historical and social cultural contents in the textbooks), international and cross-cultural level (the target language culture in different countries) and the author's point of view of teaching materials and styles.

In this paper, on the basis of the cultural content by Byram's evaluation standards, a simple statistical analysis is conducted mainly on unit themes in New Horizon College English. From the first unit theme, this textbook involves five categories of western culture, social organizations, social life, belief and behavior, social interaction and social and political construction. The following is a detailed statistics table.

TABLE I. FIVE CATEGORIES OF WESTERN CULTURE INVOLVED IN UNIT THEMES OF NEW HORIZON COLLEGE ENGLISH

\begin{tabular}{|c|c|}
\hline Western culture & Unit theme \\
\hline social interaction & $\begin{array}{l}\text { A Busy Weekday Morning in Unit2; } \\
\text { A Good Heart to Lean On in Unit 3; } \\
\text { How to Make A Good Impression in } \\
\text { Unit } 4\end{array}$ \\
\hline belief and behavior & Being Honest and Open in Unit 10 \\
\hline social and political construction & $\begin{array}{l}\text { Combat Against AIDS in Unit 5; } \\
\text { Face to Face with Guns in Unit } 7\end{array}$ \\
\hline social life & $\begin{array}{l}\text { Learning a Foreign Language in } \\
\text { Unit 1; Birth of Bright Ideas in Unit } \\
\text { 8; College Success Made Easy in } \\
\text { unit } 9\end{array}$ \\
\hline social organizations & The Trash-man in Unit 6 \\
\hline
\end{tabular}


According to the classification and statistics in above form, we can see clearly each unit theme involves many kinds of western culture with flexible style and form. As a result, students can learn about more knowledge of language and culture. The fourth unit theme of the teaching material can adapt to the development of era and meet Byram's assessment standard, namely, the teaching material shows the real and latest culture information. Culture theme in each unit doesn't involve much subject content in literature, but relates tightly to real life, which can stimulate students' interest in learning English.

\section{COllege STUDENTS' DEMAND FOR CROSS-CUlturAL COMMUNICATION CONTENT IN THE TEACHING MATERIAL}

The rapid development of information and economy in the process of globalization has to some extent accelerated the cross-cultural communication among countries around the world. As a globalized language, English is universally acknowledged as an international tool of communication, in view of which, students must be well cultivated to have a good command of English and develop their cross-cultural communication competence (also known as "intercultural communication competence”).

Cross-cultural communication competence, what's more, is also recognized and admitted as a compulsory ability which is urgently needed in the modernized education of the 21st century according to the National Medium and Long-term Education Reform and Development Planning Outline from 2010 to 2020. As is widely known to all, in modern times, English is highly concerned about by middle schools in China, which however put too much emphasis on vocabulary and grammar skills of students, lacking of specific teaching practice in intercultural communication competence and leading to students' incompetence in English language application. Teachers, needless to say, conduct English classes in the absence of context, which is bound to result in students' ignorance in intercultural communication competence. Students nowadays are unable to use English to communicate in actual context and cannot express their opinions fluently and accurately in English, for the reason of which intercultural communication competence inclusion to modern teaching goals must be paid urgent attention. Fortunately, English Curriculum Standard for Compulsory Education was released in 2011, referring to students' cultural awareness as one of the most fundamental teaching goals in the stage of elementary curriculum and emphasizing teachers' role in helping students improve their English level and add their knowledge about international culture, which provides a theoretical reference for the expansion and development of intercultural communication competence. In the light of English Curriculum Standard (2011)[4], students and teachers must make adjustment to their understanding of middle school English quality and focus more on practice of English in actual context and pay more attention to international culture. Apparently, English Curriculum Standard (2011) attaches great importance to the practical value of English, aiming to improve students' comprehensibility of international culture and practical ability of English and achieving students intercultural communication competence finally. A constant stream of newly revised textbooks emerge one by one to respond to the concept and ideology of English Curriculum Standard (2011)[5].

Foreign language teaching is supposed to cater for the needs of people to learn a foreign language, which depends on the purpose of the people to learn a foreign language. In order to learn college students' demand for cross-cultural communication content in the teaching material, the author makes a questionnaire survey among 208 college students from five undergraduate classes. The survey finds that $85 \%$ of the students cannot converse in English or speak English with foreigners; $91.6 \%$ of the students don't know how to communicate with foreigners; and $88.5 \%$ of the students don't know how to introduce Chinese traditional culture to foreigners. In view of students' demands for cultural differences, social customs, exotic, language learning, biographies and other culture related topics, the survey finds most of the students are interested in these themes, which reflects the applicability of the new textbook reform in cross-cultural content.

English, since whose function is to transmit ideas across cultures, needs its learners who come from totally different cultural and language backgrounds fully comprehend the cultural connotation hidden in language, so as to precede towards a smooth and efficient communication stage.

Cunningsworth (1995) stated that textbooks serve as major resource to achieve the teaching targets within the set of learning. That is to say, textbooks are not static tools to meet teaching targets but dynamic assistance to integrate teaching and learning. Contemporarily in China, English is regarded as foreign language in class of middle schools, but textbooks or teaching materials play a prominent role in the process, which must be revised and adjusted according to students' needs and actual learning state. In view of this, in order to accord with the criteria of English Curriculum Standard (2011), teaching content and ways of presenting teaching content must be correspondent to students' learning logics and habits and aim to deliver cultural knowledge to students, cultivating their intercultural communication competence. English Curriculum Standard can be an efficient instruction for English teaching in middle school, but textbooks' content and presentation way of cultural knowledge should be paid more attention to for the reference of teachers[6].

\section{Suggestions to Improve TeACHING Materials IN THE Light OF CROSS-CULTURAL COMMUNICATION THEORY}

Time development and the change of the international situation have proposed new requirements to English education at institutions of higher learning in our country, namely training talents provided with international consciousness and cross-cultural communication competence. Foreign language education in colleges as the main force of the domestic English education should adapt to the situation development and fuse cross-cultural communication competence into each link of education. However, in our country, there is almost no teaching material designed for cross-cultural communication competence cultivation under the guidance of relevant theories and concepts in colleges. This paper, through the analysis of and research of western culture content in New Horizon College English (the second edition), expects to assess the 
feasibility and acceptability of inclusion of cross-cultural communication content in college English textbooks and put forward the following Suggestions: Choose a wide range of cultural materials. Although the unit themes of New Horizon College English involve many kinds of western culture, considering the diversity of cultural features, there is less concern about political and social issue, which does not favor the student to have a comprehensive and objective understanding of the western society and culture and develop their critical thinking and political sensitivity in cross-cultural communication. In addition, this teaching material involves too much American culture. From a cross-cultural perspective, too much emphasis on a mainstream culture is bad for students to complete cultural system.

Refer more authentic language materials. New Horizon College English also has another big disadvantage, namely, the lack of real language materials. Real language material is main source of language input to help students to achieve effective intercultural communication. The meaning of real language materials is that it can stimulate learners' language learning motivation, provide real cultural information and place learners in real language, which can better meet the needs of learners and is helpful to use more creative teaching methods. Therefore, the author suggests that increase in reading and writing parts of teaching materials, authentic language materials such as news reports, news commentary, advertisements, magazine articles, application letter and recommendation letters should be included. Audio-visual teaching materials as closer to the oral communication, which should be included in the common scene dialogue in the real life, such as shopping, booking air tickets and airport broadcasting, etc.

Cross-cultural foreign language teaching places language skills and cultural competence in an equally important position, so learning materials should reflect the idea inevitably. If direct selecting reading materials which can reflect British and American culture regardless of Chinese culture, it is easy to form the gap between the English and Chinese traditional culture. Therefore, the teaching material of college English should be selected and reformed to pay attention to combining the diversified contents of the cross-cultural communication, so as to promote the students' learning motivation and let the students learn to communicate intercultural in English.

\section{REFERENCES}

[1] Hu Wenzhong. An introduction to intercultural communication 〔M]. Beijing: foreign language teaching and research press. 1999

[2] Dubin.FD.,\& Olstein,E. Cousre Design [M].Shanghai: Shanghai Foreign Language Press.2001.

[3] Hymes, D.H.On Communicative Competence [M]. Philadelphia: University of Pennsylvania Press.

[4] Chen Xuefen. Research on the change of China's English education[M]. Hangzhou: Zhsejiang University Press,2011.

[5] Guo Yanhong, Zhan Chunyan. A study on the effect of college English teaching material investigation on teacher professional development[J]. Foreign Language World,2011,(4):67-74.

[6] Byram M. \& V. Esarte-Satties. Investigating Cultural Studies in Foreign Language Teaching[M]. Clevedon: Multilingual Matters, 1991 